\title{
Physiotherapy Students Willingness to Report Misconduct to Protect the Patient's Interests in Chennai
}

\author{
D. Malarvizhi' ${ }^{1}$, Bhagya Lakshmi K. ${ }^{2}$, Hariharan S. ${ }^{2}$ \\ ${ }^{1}$ Prof. Dean, ${ }^{2}$ BPT IV YEAR Student, SRM College of Physiotherapy, SRM Institute of Science and Technology, \\ Kattankulathur, Chengalpattu, Tamil Nadu, India
}

\begin{abstract}
Background: Applying the ethics in practice is more essential than just learning it. Any sought of misconduct to the patient is not just an ethical issue but it will also degrade the professionalism and it brings a sense of insecurity in patients and this will slow down the progress of treatment. So it is not only important to avoid the ethical issues and misconduct but it is also necessary to stand against ethical issues that happen within the organization that may done by colleagues or higher authorities without any dilemma. OBJECTIVE: This study aims to find out the difficulties and dilemmas of the physiotherapist in ethical decision making and disclosing the misconduct of their colleagues without any hesitation. METHODOLOGY: A close ended questionnaire was used to assess the willingness of the student physiotherapist to expose the misconduct which might be an internal or external disclosure. The questionnaire consisted of two clinical scenarios which were most likely to arise in a work place. Each scenario consisted of 5 questions that rated the severity, likelihood of confronting, internal disclosure, external disclosure to the association and external disclosure to media. The scoring was based on five point likert scale. It was a study that was done with convenient sampling method. The questionnaire was given to 100 Physiotherapy students in Chennai of both the sexes who were willing to participate in the study.RESULT: From the statistical analysis, there is a significant difference obtained for the likelihood of reporting the manager's misconduct than colleague's misconduct. Also their willingness to report internally within the organization is greater than that of reporting externally to the association and to the media.CONCLUSION: Ethics being a part of Physiotherapy curriculum, these students have well understood the ethical and professional behavior and have good ethical acceptance. Hence we conclude that the students do understand the seriousness of any misconduct of a therapist to the patient and are willing to expose any misconduct they encounter to the internal or external environment.
\end{abstract}

Keywords: Ethics, Students, Physiotherapy, Misconduct, Ethical dilemma

\section{Introduction}

Whistle blowing is usually defined as the reporting "by organization members (former or current) of illegal, immoral, or illegitimate practices under the control of their employers to persons or organizations that may be able to effect action" ${ }^{1}$. Reporting any sought of unethical behaviour is more inevitable and essential in the field of health sciences as it is concerned with human lives. Whistle blowing largely helps in the reducing the rates of misconduct in future ${ }^{2,3}$. But still blowing a whistle against the organisation or colleague or a superior is a major dilemma faced by an individual because when blowing a whistle, it not only involves the whistle blower and the organisation but it also involves the patient who is actually affected, this will lead to deterioration of the hospital's fame. This will put the whistle blower at risk ${ }^{1,2}$. All though whistle blowing is a moral behaviour, it will risk the life of the one who reports the misconduct. The person who voluntarily reports the misconduct might be exploited and might end up in losing his livelihood ${ }^{1,4}$. Despite these consequences it is to be noted that those who are with high self-ideals are the one to report the misconduct as they are ones intolerable to the unethical behaviour ${ }^{4}$. It must also be noted that a person will hesitate to report his friend if found guilty because of their bond or because of the fear that they might get caught one day ${ }^{5}$. 
When a person is dishonest or unethical during his student life then there are high chances that he will be more deviant during his professional life ${ }^{5}$. Any unethical behaviour as a professional will lead to distrust of patients and a sense of insecurity which in turn reduces the progress in the patient condition that will lead to ending up of the professional's career ${ }^{6}$. This is the reason why any sought of unprofessional behaviour has to reported and stopped immediately.Since ethical acceptance begins at the college level ${ }^{7}$, it is important to know level of ethical knowledge and their willingness to follow ethics and their ability to make decisions in critical cases and their willingness to report the unethical behaviour that is either conducted by their superior or their colleague. Though this subject is of high importance there are not enough researches done in India to find out about the ethical dilemmas and decision making related to physiotherapy. Our study aims to find out how well the students are able to understand the seriousness of the misconduct of the therapist to the patient and how willing are they to expose any misconduct they encounter to the internal or external environment. Internal disclosure implies reporting misconduct to an higher authority within the organization. External disclosure implies reporting misconduct outside the organization such as law enforcement or media

\section{Materials and Methodology}

Based on the selection criteria only physiotherapy students of UG final year, PG first and second year and interns those who were pursuing their degree in
Chennai were selected as participants. Departmental ethical committee approval was obtained. A total of 100 participants were aimed and a closed ended questionnaire was sent as google forms. Students from colleges without ethics as a part of curriculum were excluded. Initially the participants were asked to fill the demographic data that included the name, age, college they belonged to, and the year they were studying. The questionnaire consisted of 2 clinical scenarios and 5 set of questions were asked under each scenario. The first scenario was related to colleague's misconduct and the second one was concerned with the misconduct by the higher official. The first question dealt with how far the students were able to understand the seriousness of the situation while the second question dealt with the student's willingness to confront the misbehaviour to the one who committed it and insisting him to correct what he did. Question 3 and 4 dealt with blowing whistle to the internal environment. Question 5 is related to the blowing of whistle to the external environment. All the questions were rated according to 5-point likert scale. The answer for the first question ranged from "very serious" to "not serious at all". The answers for the remaining four questions ranged from "strongly agree" to "strongly disagree".

\section{Results}

The mean differences between the groups were assessed using the paired sample's test. The data were analyzed using SPSS statistical software, PC version 20.0

Table 1: Comparison between the respondents' scores for the two case stories regarding the severity of the misconduct, the likelihood of taking action to change the situation and the indices of internal and external whistle blowing.

\begin{tabular}{|c|c|c|c|c|c|}
\hline & \multirow{2}{*}{ Sample } & \multicolumn{2}{|c|}{$\begin{array}{l}\text { Case story } 1 \text { colleague } \\
\text { misconduct (n 100) }\end{array}$} & \multicolumn{2}{|c|}{$\begin{array}{l}\text { Case story } 2 \text { director } \\
\text { misconduct (n 100) }\end{array}$} \\
\hline & & Mean & SD & Mean & SD \\
\hline 1. Severity of the misconduct & 100 & 3.75 & 0.989 & 4.03 & 0.915 \\
\hline $\begin{array}{l}\text { 2. Likelihood of taking action by confronting the person } \\
\text { responsible for the wrongdoing to repair the harm done }\end{array}$ & 100 & 3.84 & 0.861 & 4.04 & 0953 \\
\hline $\begin{array}{l}\text { 3. Internal whistle blowing: likelihood of reporting the } \\
\text { misconduct to someone in the workplace }\end{array}$ & 100 & 3.51 & 1.010 & 3.78 & 1.069 \\
\hline $\begin{array}{l}\text { 4. External whistle blowing: likelihood of reporting the } \\
\text { misconduct to the Physical Therapists' Association }\end{array}$ & 100 & 3.43 & 1.037 & 3.64 & 0.802 \\
\hline $\begin{array}{l}\text { 5. External whistle blowing: likelihood of reporting the } \\
\text { misconduct to the media }\end{array}$ & 100 & 3.15 & 1.086 & 3.65 & 1.029 \\
\hline
\end{tabular}


Table 1 shows the comparison between the respondents' scores for the two case stories regarding the severity of the misconduct, the likelihood of taking action to change the situation and the indices of internal and external whistle blowing.

Table 2: Paired sample test

\begin{tabular}{|c|c|c|c|c|c|}
\hline \multicolumn{6}{|c|}{ Paired Samples Statistics } \\
\hline & & Mean & $\mathbf{N}$ & $\begin{array}{c}\text { Std. } \\
\text { Deviation }\end{array}$ & Sig. \\
\hline \multirow{2}{*}{$\begin{array}{l}\text { Pair 1: Internal whistle } \\
\text { blowing reporting to a } \\
\text { superior in the work place }\end{array}$} & $\begin{array}{l}\text { If you decide not to talk to your colleague, or if you have talked to } \\
\text { her about the matter and not succeeded in getting her to report the } \\
\text { incident, how likely is it that you will go to someone at the center } \\
\text { who has the power to intervene, such as the head of physiotherapy } \\
\text { ward or ethics comitee,or if snyone is at the rehablitationcentre }\end{array}$ & 3.51 & 100 & 1.010 & \multirow{2}{*}{.010} \\
\hline & $\begin{array}{l}\text { If you decide not to talk to the director, or if you have talked to } \\
\text { her and not been able to change her mind, how likely is it that you } \\
\text { will report the directorâ } €^{\mathrm{TM}_{\mathrm{S}}} \text { intentions to someone at the center } \\
\text { who has the power to intervene, such as the centerâ€ } €^{\mathrm{TM}} \mathrm{S} \text { genral } \\
\text { director or ethics comitee if any one is at the centre }\end{array}$ & 3.78 & 100 & 1.069 & \\
\hline \multirow{2}{*}{$\begin{array}{l}\text { Pair 2: External whistle } \\
\text { blowing reporting to } \\
\text { the physical therapists } \\
\text { association }\end{array}$} & $\begin{array}{l}\text { If you decide not to approach anyone at the centre, or if you } \\
\text { do talk to someone and he or she does nothing to intervene, } \\
\text { how likely is it that you will turn to the Physical Therapists' } \\
\text { Association, an external body }\end{array}$ & 3.43 & 100 & 1.037 & \\
\hline & $\begin{array}{l}\text { If you do not refer the matter to an authority at the centre, or if } \\
\text { you do and he or she does not intervene in the director's decision, } \\
\text { how likely is it that you will turn to the Physical Therapists' } \\
\text { Association, an external authority? }\end{array}$ & 3.64 & 100 & 0.802 & .016 \\
\hline $\begin{array}{l}\text { Colleague's report to } \\
\text { media }\end{array}$ & $\begin{array}{l}\text { If you decide not to report the matter to the Physical } \\
\text { Therapistsâ } €^{\mathrm{TM}} \text { Association, or if you do talk to them and they } \\
\text { do nothing, how likely is it that you will report the matter to the } \\
\text { media? }\end{array}$ & 3.15 & 100 & 1.086 & \multirow[t]{2}{*}{.056} \\
\hline $\begin{array}{l}\text { Pair 3: Director report to } \\
\text { media }\end{array}$ & $\begin{array}{l}\text { If you decide not to report the matter to the Physical Therapists } \\
\text { Association, or if you do talk to them and they do nothing, how } \\
\text { likely is it that you will report the matter to the media? }\end{array}$ & 3.65 & 100 & 1.029 & \\
\hline
\end{tabular}

Table 1 shows the comparison between the respondents' scores for the two case stories regarding the severity of the misconduct, the likelihood of taking action to change the situation and the indices of internal and external whistle blowing. From the scores obtained, the likelihood of reporting director's misconduct is higher than that of colleague's misconduct.

Table 2 shows the comparison between the scores of the internal and external whistle blowing to the association and to media. From the scores obtained, the likelihood for internal whistle blowing is higher than that of external whistle blowing. There is a significant difference $(0.010)$ between the internal whistle blowing for colleague and director misconduct. There is a significant difference (0.016) between the external whistle blowing for colleague and director misconduct in reporting to the physical therapy association. There is a non-significant difference (0.056) between the external whistle blowing for colleague and director misconduct in reporting to the media.

\section{Discussion}

The purpose of this study is to find out how well the students are able to understand the seriousness of the misconduct of the therapist to the patient and how willing are they to expose any misconduct they encounter to the internal or external environment. Totally 100 physiotherapy students with ethics as a part of curriculum were taken into consideration out of which 58 female and 42 male students have participated. From the study it is found that the physiotherapy students witnessed the situations that are harmful to the patients to be very serious. In such situations, they are likely to report to the higher authorities in both cases 
of misconduct by their colleague as well as manager. However the rate of likelihood to report varied between both the case stories. Hence there was a significant difference obtained by the statistical analysis of the obtained data. From the scores obtained the likelihood of considering the severity of misconduct, confronting the person responsible for the wrongdoing, reporting the misconduct to someone in workplace, to the association or to the media for the director's misconduct was higher than that of colleague's misconduct. This shows that the students give more importance to the interest of patient rather than supporting the misconduct of colleague or manager. In situations where such misconduct arises their willingness to report seems to be expressed rather than supporting the misconduct. Similarly the scores obtained for internal whistle blowing was higher than that of external whistle blowing. The reason for this might be because the students prioritize to report to the superior authority within the organization than disclosing it outside the organization ${ }^{8}$. Also Abraham Mansbach et al., (2011) has stated that the students prefers and follows a pattern of internal whistle blowing after which the external whistle blowing is being is approached rarely ${ }^{9}$. Anna Myers., (2008) has also stated that it is wiser to whistle blow first internally and then externally outside the organization. It is more ethical and also being loyal to the organization ${ }^{10}$. While also expresses that whistle blowing to an unethical or a deviant act is a core component of an employee and that at all costs whistle blowing to root out a criminal activity which is possibly harmful to the client or the reputation of the institution must be encouraged ${ }^{11}$.

\section{Conclusion}

Ethics being a part of Physiotherapy curriculum, these students have well understood the ethical and professional behavior and have good ethical acceptance. Hence we conclude that the students do understand the seriousness of any misconduct of a therapist to the patient and are willing to expose any misconduct they encounter to the internal or external environment.

The limitation and recommendation of the study are The answer that was recorded by the participants was just their interest and opinion towards whistle blowing as a student. But the actual response that they give when they are into the situations might vary. In future studies can be done with a comparison between physiotherapy students with and without ethics as a part of curriculum.
In future studies can be done with a comparison between physiotherapy students and practitioners.

Ethical Clearance: Departmental Ethical clearance was obtained.

\section{Conflict of Interest: Nil}

\section{Source of Funding: Self}

\section{References:}

1. Mansbach A, Kushnir T, Ziedenberg H, Bachner YG. Reporting misconduct of a coworker to protect a patient: a comparison between experienced nurses and nursing students. The scientific world journal. 2014;2014

2. Mansbach A, Bachner YG. Internal or external whistleblowing: nurses' willingness to report wrongdoing. Nursing Ethics. 2010 Jul;17(4):48390.

3. Ray SL. Whistleblowing and organizational ethics. Nursing ethics. 2006 Jul;13(4):438-45.

4. C.Fred Alford. Ithaca, NY; Whistleblowers: Broken Lives and Organizational Power. Cornell University press,2001 17pp.

5. Abdulghani HM et.al, Self-reported cheating among medical studuents: An alarming finding in a cross-sectional study from Saudi Arabia,PLoS ONE(2018)13(3)

6. Paul S Mueller et.al, Teaching and Assessing Professionalism in Medical Learners and Practicing Physicians. Ramban Maimonides Med J 2015;6(2)

7. Dworkin TM, Baucus MS. Internal vs. external whistleblowers: A comparison of whistleblowering processes. Journal of business ethics. 1998 Sep 1;17(12):1281-98

8. Abraham Manasbachet.al, Physiotherapy students willingness to report misconduct to protect the patient's interest J Med Ethics 2010 36:802-805.

9. Mansbach A, Bachner YG, Melzer I. Physical therapy students' willingness to report misconduct to protect the patient's interests. Journal of medical ethics. 2010 Dec 1;36(12):802-5.

10. Myers A. How to blow the whistle safely, Nursing Standard (through 2013). 2008 Feb 27;(25):24

11. Dungan J, Waytz A, Young L. The psychology of whistleblowing. Current Opinion in Psychology. 2015 Dec 1;6:129-33. 